\title{
HADIS PENGAKUAN ATAS HAK-HAK PEREMPUAN: Reinterpretasi Muhammad Al-Ghazali
}

\author{
MUHAMMAD MUNDZIR, RANIA NURUL RIZQIA \\ UIN Sunan Kalijaga \\ Yogyakarta, Indonesia
}

Email: munmundzir@gmail.com, Ranianrizkia@gmail.com

\section{Abstrak}

Discrimination on women's rights is still became a trending topic in the Post-Truth Era. Women still got different treatment in the view of some of ustaz. This can be found in one of the Youtube's videos, an ustaz said that women need not be given an understanding of gender. As a result, it creates a paradigm that women do not have a role and existence in the Post-Truth Era. Fortunately, this paradigm contradicts the hadith narrated by Ibn Abbas, that Allah recognized women as human beings who are equal to men. To examine this hadith, the author focuses on the thought of Muhammad Al-Ghazali, who offers 4 principles to understanding hadith, namely the hadiths are not contradicted with the Qur'an, comparing with other hadith, correlating with history, and not contradicted with scientific truth. The result of understanding of the hadith is that every human being has the right to be existent. Women during the time of the Prophet did not have the right to express theirself because they were influenced by the culture of Jahiliah. So, by analyzing linguistic and gender aspects, women should have the equal rights to men.

\section{Keywords}

Al-Ghazali, Hadis, Hak-hak Perempuan, Reinterpretasi

\section{Pendahuluan}

Diskriminasi terhadap hak-hak perempuan masih menjadi sebuah problematik di Indonesia. Perempuan masih dijustifikasi sebagai sumber problematik di masyarakat. 
Ditambah ceramah salah satu ustaz di media sosial yang melarang untuk mengajarkan kesetaraan gender kepada perempuan. Menurutnya, perempuan sudah dimuliakan dalam perspektif Alquran dan hadis, selain itu Nabi juga melarang penindasan terhadap kebebasan perempuan di ranah publik. ${ }^{1}$ Akan tetapi, praktik di lapangan menunjukkan bahwa perempuan masih mendapatkan perlakuan tidak adil untuk tampil sebagai makhluk yang memiliki hak secara utuh. Akibatnya, muncullah beberapa komunitas dan golongan untuk menyuarakan haknya sebagai manusia yang normal.

Sudah menjadi kewajiban bagi seorang muslim untuk turut menyuarakan hak-hak perempuan. Hal itu dilandasi adanya teks hadis yang mewajibkan manusia untuk berbuat baik kepada wanita. $^{2}$ Selain itu, Islam sebagai agama yang rahmat bagi seluruh makhluk mewajibkan untuk memuliakan hak-hak setiap makhluk, bukan sebaliknya. Teks-teks keagamaan utamanya Alquran dan hadis telah banyak berbicara terkait kemuliaan wanita. Akan tetapi usaha untuk memahami Alquran dan hadis yang sesuai dengan zaman dan makan masih minim dilakukan. Hal tersebut dilatarbelakangi pemahaman-pemahaman seseorang yang berasal dari luar negeri kemudian dijadikan hujjah di Indonesia. Bukan berarti seluruh pemikir dari luar tidak sesuai dengan konteks

1 Jangan Ajari Umat Islam tentang Kesetaraan Gender - Ustadz Adi $\begin{array}{llll}\text { Hidayat, } & \text { diakses } & \text { September }\end{array}$ https://www.youtube.com/watch?v=5bjcY6qIun4.

2 Abu Abdullah Muhammad bin Ismail bin Ibrahim bin Al-Mughiroh Al-Bukhari, Shahih Bukhari (Daar Ibn Katsir, 1993), No. 4787; Abu Al-Husain Muslim bin Al-Hajjaj bin Muslim Al-Qusyairi An-Nisabury, Shahih Muslim (Beirut: Daar al-Kutub al-Ilmiyah, 1992), No: 2671; Ibn Majah Abu Abdullah Muhammad bin Yazid Al-Quzwainiy, Sunan Ibn Majah (Daar Ihya' al-Turats al-Arabiy, t.t.), No: 1841.

TAHDIS Volume 10 Nomor 2 Tahun 2019 
Indonesia, terdapat beberapa pemikir yang dijadikan pegangan untuk mengembangkan pemahaman teks keagamaan. ${ }^{3}$

Salah satu tokoh pemikir hadis kontemporer dari luar Indonesia adalah Muhammad al-Ghazali. Al-Ghazali adalah ulama kontemporer yang hidup di abad 20 dengan menghabiskan hidupnya untuk berdakwah dan berkontribusi dalam studi hadis. Meskipun karya-karyanya menuai kontroversi di kalangan ulama kontemporer, bahkan ia mendapat justifikasi sebagai munkir al-sunnah tetapi pemikirannya dalam menjunjung tinggi hak-hak perempuan perlu diapresiasi. Quraish Shihab adalah salah satu tokoh yang mengapresiasi positif pemikiran al-Ghazali, karena pemahaman beliau dapat memberikan solusi-solusi terhadap permasalahan di Indonesia. ${ }^{4}$ Selain itu, al-Ghazali juga sering mengkritik orang-orang yang sedang mendalami studi Fiqh tanpa mendalami ilmu hadis, dan sebaliknya. ${ }^{5}$ Meskipun demikian, pemikiran dan tawaran al-Ghazali untuk memahami hadis belum sepenuhnya sempurna.

Metode pemahaman hadis yang ditawarkan oleh alGhazali adalah sebuah tawaran baru di era kontemporer yang akhirnya dikembangkan oleh muridnya Yusuf al-Qardhawi. AlGhazali menawarkan lima prinsip untuk memahami suatu hadis, tetapi prinsip tersebut tidak berurutan dan belum dapat diaplikasikan dalam pemahaman hadis secara komprehensif. Hal ini tidak menutup kemungkinan jika metode tersebut dapat diaplikasikan untuk memahami hadis tentang pengakuan hak2019).

${ }^{3}$ Faqihuddin Abdul Kodir, Qira'ah Mubadalah (Yogyakarta: IRCiSoD,

4 Sri Purwaningsih, "Kritik Terhadap Rekonstruksi Metode Pemahaman Hadis Muhammad Al-Ghazali," Jurnal THEOLOGIA 28, no. 1 (14 September 2017): 77, https://doi.org/10.21580/teo.2017.28.1.1189.

5 Muhammad Al-Ghazali, Al-Sunnah Al-Nabawiyyah baina Ahli alFiqh wa Ahli al-Hadis (Mesir: Daar al-Kitab al-Mishriy, 2012). 
hak perempuan. Tentu, dengan melihat kondisi sosial politik di Indonesia. Maka dari itu, dalam kajian ini ada dua hal yang dibahas, yaitu bagaimana al-Ghazali memahami hadis dan bagaimana penerapan metode yang ditawarkan tersebut untuk memahami hadis tentang pengakuan hak-hak perempuan. Sebagai sumber data dalam kajian ini, penulis mengutamakan karya-karya al-Ghazali dan karya ulama yang mengkritik alGhazali, selain itu penulis juga menggunakan buku lain untuk menganalisis. Untuk mempertajam analisis kajian ini, penulis juga menggunakan pendekatan ilmu hadis dan keilmuan umum.

\section{Pemahaman Hadis Muhammad Al-Ghazali}

Salah satu karyanya yang fenomenal adalah kitab alSunnah al-Nabawiyyah baina al-Fiqh wa Ahl al-Hadis. Buku ini telah dialihbahasakan ke dalam bahasa Indonesia dengan judul buku Studi Kritis atas Hadis Nabi saw. Korelasi antara Alquran dan hadis menjadi salah satu topik yang selalu dibahas oleh Muhammad al-Ghazali, khususnya dalam kitab tersebut. Ia berpendapat bahwa Alquran merupakan undang-undang Islam dan hadis adalah tata cara implementasi daripada undangundang Islam. Tidak ada yang bisa mengganggu gugat, bahwa hadis sama pentingnya dengan Alquran, karena segala apa yang dilakukan, dikatakan oleh Nabi bukanlah semata lahir dari dirinya pribadi, namun semua itu juga berasal dari Allah Swt. ${ }^{6}$ Selanjutnya ia juga mengemukakan pandangannya terhadap korelasi antara Alquran dan hadis. Menurutnya Sunnah haruslah dipahami dalam kerangka Alquran, dan juga sebaliknya Alquran itu sendiri tidak dapat dipahami seutuhnya

${ }^{6}$ Muhammad Al-Ghazali, Fiqhu al-Sirah (Kairo: Dar ar-Rayyan Li atTurats, 1987). Hlm. 40

TAHDIS Volume 10 Nomor 2 Tahun 2019 
jika tanpa disertai dengan pemahaman hadis. Hal ini didasarkan pada sabda Rasulullah saw.

Dari 'Abdu al-Rahman bin Abi 'Auf al-Jurassyi dari alMiqdam bin Ma'di. Rasulullah saw. bersabda "Ketahuilah bahwa saya telah membawa Alquran dan yang sama dengannya, yaitu hadis."

Berangkat dari hal tersebut ia kemudian mengkritik para ahli hadis yang tidak menyertakan berbagai keilmuan atau pengetahuan lain yang berkaitan dengan hadis yang ia berusaha pahami. Muhammad al-Ghazali kemudian memiliki lima kriteria untuk syarat sebuah hadis dapat dinyatakan sebagai hadis yang Shahih. Pertama, seorang perawi hadis wajib seseorang yang memahami serta meyakini betul apa yang didengarnya, teliti, serta cerdas dalam menghafal. Kedua, seorang perawi harus merupakan pribadi yang bertakwa kepada Allah Swt serta dapat melawan segala bentuk pemalsuan ataupun penyimpangan hadis. Ketiga, baik keadilan maupun kedhabitan tersebut harus dimiliki oleh setiap perawi yang ada di dalam runtutan para perawi sebuah hadis tertentu. Yang artinya, jika ada satu saja perawi dalam satu rangkaian sanad hadis yang tidak memenuhi seluruh syarat tersebut, maka hadis tidak bisa dinyatakan sebagai hadis yang Shahih. ${ }^{7}$ Keempat, tidak terdapat syadz dalam matan hadis. Syadz adalah jika didapati adanya pertentangan periwayatan dengan perawi yang telah diakui lebih adil maupun dhabit. Maka, hadis menjadi berstatus dhaif apabila matannya bertentangan atau berlainan dengan hadis (ahad maupun mutawattir) yang riwayatnya lebih kuat, apalagi jika bertentangan dengan ayat Alquran. Kelima, matan hadis tidak boleh mengandung Illah Qadihah, yakni cacat dalam matan yang telah masyhur

7 Muhammad Al-Ghazali, Studi Kritis atas Hadis Nabi (Bandung: Mizan, 1996), 26. 
diketahui oleh para ahli hadis. ${ }^{8}$ Melihat kepada lima poin di atas, terdapat satu poin yang hilang dari syarat Shahih yang dirumuskan oleh para ahli hadis sebelumnya, yakni ketersambungan sanad. Hal tersebut belum diketahui adanya, apakah ia sengaja menghilangkan poin tersebut atau tidak. Namun, kesengajaan tersebut bukanlah hal yang mustahil jika melihat pada akar keresahannya terhadap kajian hadis saat itu.

Muhammad al-Ghazali merasa para ahli hadis terlalu memberikan porsi besar terhadap ilmu jalur transmisi sanad, dibuktikan dengan lebih banyaknya karya kitab hadis yang mengulas tentang sanad dibandingkan dengan kitab yang mengulas matan hadis. Beliau kemudian hadir memberikan kritik. Seharusnya umat Islam mampu menelaah hadis dari kedua sisi matan dan sanad dengan porsi yang seimbang. Menurutnya, manusia yang kritis adalah mereka yang dapat menelaah hadis dari dua sisi tersebut. Sisi matan yang merupakan sisi internal hadis, dan juga sisi sanad yang merupakan sisi eksternal hadis. Saat matan telah dihukumi shahih belum tentu sanadnya juga shahih, begitu pula sebaliknya. Hal yang mungkin juga terjadi adalah sanad yang shahih kemudian diragukan kembali keshahihannya saat ditemukan cacat di dalam redaksi matan hadisnya. Saat meneliti matan maupun sanad, akallah yang berperan dalam menilai serta memberi keputusan ada atau tidaknya kecacatan dalam matan ataupun kecacatan pada kualitas perawi suatu hadis. ${ }^{9}$

Dengan keberaniannya menyampaikan kritik terhadap hadis-hadis shahih, pada akhirnya ia juga banyak menuai

${ }^{8}$ Muhammad Al-Ghazali, At-Thariq min Huna (Mesir: Daar Syuruq, 1992), 57.

9 Muhammad Al-Ghazali, Laisa min al-Islam (Kairo: Maktabah Wahbah, 1991), 38.

TAHDIS Volume 10 Nomor 2 Tahun 2019 
kritikan. Kritik yang ditujukan kepadanya biasanya berdasarkan dua pemikiran Muhammad al-Ghazali. Pertama, karena dia enggan menggunakan hadis-hadis ahad dalam perkara akidah. Menurutnya, hal-hal terkait akidah harus berdasarkan sebuah keyakinan, bukan sebuah dugaan. Ia juga menambahkan bahwa walaupun hadis ahad tersebut shahih, namun hadis ahad tidak dapat memberikan yaqin (keyakinan), hanya hadis mutawattir yang dapat memberikannya. Hal tersebut sebetulnya telah dijelaskan secara konkret oleh ayat Alquran. Yakni pada surah al-Najm ayat 28, ketika ayat tersebut menggambarkan penghinaan Allah terhadap kaum musyrikin yang dalam mendasarkan kebenaran pada dalil yang bersifat praduga atau dzann.

Artinya

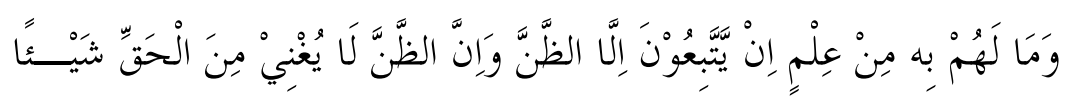

Dan mereka tidak mempunyai ilmu tentang itu. Mereka tidak lain hanyalah mengikuti dugaan, dan sesungguhnya dugaan itu tidak berfaedah sedikit pun terhadap kebenaran.

Kedua, Muhammad al-Ghazali menolak penuh terhadap hadis-hadis ahad yang ia anggap tidak sesuai dengan Alquran, fakta-fakta historis atau dengan logika ilmu pengetahuan. Maka dapat dilihat bahwa Muhammad al-Ghazali sebetulnya mempunyai cara yang tidak jauh berbeda dengan para ahli hadis dalam merumuskan kriteria shahih. Yang berbeda adalah saat ia dihadapkan kepada keshahihan matan hadis, karena ia memprioritaskan syarat bahwa matan hadis haruslah sesuai dengan prinsip ayat-ayat Alquran. ${ }^{10}$

Dalam Al-Sunnah al-Nabawiyyah Baina Ahl al-Fiqh wa Ahl al-Hadis, Muhammad al-Ghazali mempertanyakan kembali 
hadis-hadis shahih yang menurutnya bertentangan dengan Alquran, historis, maupun kebenaran ilmiah. Selain itu ia juga menolak hadis yang menurutnya tidak fleksibel dalam perkembangan zaman. Mengingat bahwa dalam suatu hadis terdapat berbagai macam petunjuk dari berbagai sisi keilmuan. Ia kemudian menambahkan bahwa dalam merealisasikan berbagai metodenya, seorang para ahli hadis wajib bekerja sama dengan berbagai ahli dalam bidang keilmuan lain. Di antaranya adalah para ahli fiqih, ahli ushul fiqih maupun para ahli ilmu kalam. Dalam hal meneliti sebuah hadis, seorang ahli hadis berada di posisi seseorang yang harus meneliti hadis pada ranah kualitas sanad dan matannya. Sedangkan para ahli keilmuan lainnya membantu untuk menemukan adanya cacat atau kekeliruan yang dilakukan oleh seorang perawi yang mungkin saja menimbulkan kecacatan yang tersembunyi di dalam matan hadis. ${ }^{11}$

Dalam berbagai karyanya, Muhammad al-Ghazali tidak menjelaskan secara detail bagaimana tahapan-tahapan dalam memahami sebuah hadis Nabi hingga sampai dianggap relevan dengan perkembangan zaman. Langkah-langkah metode Muhammad al-Ghazali sebetulnya terlihat sangat jelas dalam pembahasan beberapa hadis di dalam karyanya al-Sunnah alNabawiyyah baina Ahl al-Fikh wa Ahl al-Hadis. Beberapa ciri khas Muhammad al-Ghazali dalam memahami hadis kemudian dipetakan oleh Suryadi menjadi 4 garis besar tahapan pemahaman hadis.

1. Pengujian dengan Alquran.

Dalam poin ini hadis harus terlebih dahulu diuji dengan Alquran demi menentukan validitasnya. Apakah dalam hadis tersebut termuat prinsip-prinsip Alquran dan tidak 
bertentangan dengan ayat Alquran. Menurut Muhammad alGhazali hal ini juga telah dilakukan oleh para sahabat Nabi. Salah satunya adalah 'Aisyah. Ia mengkritisi hadis yang diriwayatkan oleh Umar bin al-Khattab terkait menderitanya orang telah meninggal akibat dari ratapan keluarganya.

2. Konfirmasi Hadis Dengan Hadis Lain.

Dalam membahas suatu hadis, para ahli hadis tidak boleh membahasanya secara parsial tanpa mengaitkan dengan hadis-hadis yang masih terkait pembahasannya. Karena jika hal tersebut ditinggalkan, makna yang ditemukan mungkin akan menjadi sangat kaku serta akan menyulitkan untuk menemukan makna hadis secara utuh.

3. Pengujian dengan Fakta Historis.

Dalam memahami hadis, kita juga tidak boleh melewatkan fakta sejarah terkait hadis tersebut. Hadis haruslah memiliki hubungan serta saling menguatkan dengan fakta sejarah, barulah ia mendapatkan status validitas yang kokoh. Jika ditemukan perbedaan di antara fakta sejarah, maka keduanya harus dipertanyakan kembali kebenarannya.

4. Pengujian dengan Kebenaran Ilmiah.

Yang terakhir adalah hadis haruslah dicocokkan dengan kebenaran ilmiah. Atau ilmu pengetahuan yang telah berkembang pada masa hadis tersebut berusaha dipahami. Hal tersebut akan menghantarkan sebuah pemaknaan kontekstualisasi hadis yang nantinya akan mewarnai gaya pemaknaan Muhammad al-Ghazali dalam setiap karyanya. ${ }^{12}$

12 Suryadi, Metode Kontemporer Memahami Hadis Nabi (Yogyakarta: Teras, 2008). Hlm. 85. 


\section{Kontestasi Pemahaman Hadis Pengakuan atas Hak-hak Perempuan}

Ulama hadis telah mengklasifikasikan bahwa periwayatan hadis memiliki dua klasifikasi, yakni riwayat billafdzi dan bil ma'na. Riwayat billafdzi adalah riwayat yang redaksinya sama dari zaman Nabi sampai mukharrij. Sedangkan riwayat bilma'na adalah riwayat yang redaksinya tidak sama dari zaman Nabi sampai mukharrij, tetapi makna yang dimaksud Nabi telah tersampaikan kepada periwayat hadis. ${ }^{13}$ Melihat kondisi di atas, para periwayat hadis pada zaman dahulu telah menggunakan nalar pikirannya untuk memahami sebuah hadis, meskipun lafaznya yang berbedabeda, tetapi maknanya masih memiliki kandungan hadis yang disampaikan Nabi pertama kali. Selain itu, yang perlu diperhatikan bahwa pemahaman periwayat hadis belum menjembatani untuk diaplikasikan dengan konteks sekarang. Mereka masih cenderung untuk menjaga kemurnian hadis yang pertama kali disampaikan.

Model periwayatan bilma'na berpengaruh kepada pemahaman penerima hadis selanjutnya. Dinamika pemahaman hadis yang berkelanjutan memiliki ruang lingkup yang berbeda. Pada zaman Nabi sampai mukharrij periwayatan bilma'na yang hasilnya masih berputar dengan kondisi sosial di

13 Pada zaman Nabi, semangat untuk mendengarkan apa yang disampaikan oleh Nabi masih kuat, sehingga para sahabat masih cenderung untuk menghafal dari pada memahami. Meskipun terdapat beberapa sahabat yang bertanya ketika kurang paham dengan apa yang disampaikan Nabi. Selain itu, intelektualitas para sahabat berbeda-beda juga menjadi tolok ukur adanya varian redaksi dan makna hadis. Hadis-hadis yang diriwayatkan secara bilma'na mayoritas adalah hadis-hadis qauli. Sahabatsahabat yang memperkenankan periwayatan bilma'na antara lain Ali bin Abi Thalib, Ibn 'Abbas, Ibn Mas'ud, Anas bin Malik, dll. Lihat Muhammad Alfatih Suryadilaga, Ilmu Sanad Hadis (Yogyakarta: Idea Press, 2017), 30. Syuhudi Ismail, Kaidah Kesahihan Sanad Hadis, IV (Jakarta: PT. Bulan Bintang, 2014), 76.

TAHDIS Volume 10 Nomor 2 Tahun 2019 
era zaman Nabi. Sedangkan zaman mukharrij sampai sekarang periwayatan bilma'na menghasilkan pemahaman yang berbeda dengan zaman dahulu, karena problematik dan konteks zaman sekarang telah berubah. Dalam tulisan ini, penulis akan mengklasifikasikan pemahaman hadis terkait pengakuan hakhak perempuan.

Adapun redaksi hadis tersebut adalah:

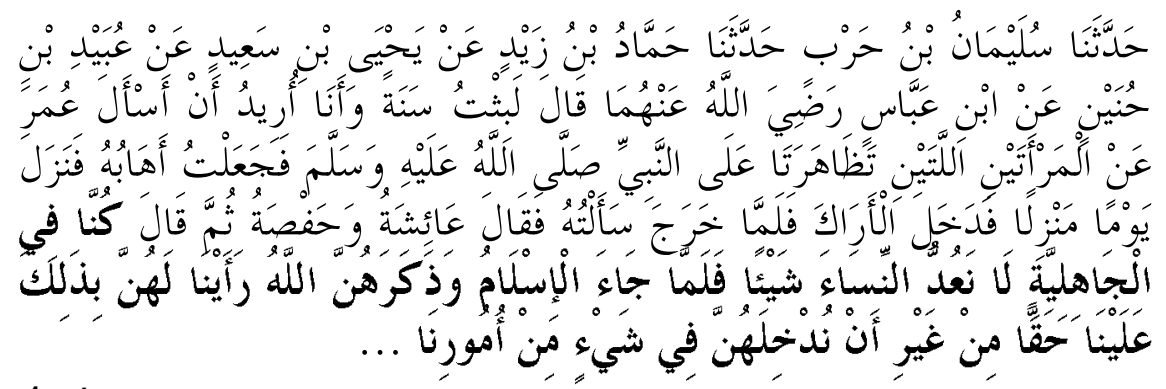

Artinya

Telah menceritakan kepada kami Sulaiman bin Harb telah menceritakan kepada kami Hammad bin Zaid dari Yahya bin Sa'id dari 'Ubaid bin Hunain dari Ibnu Abbas radliallahu 'anhuma dia berkata; telah setahun lamanya saya hendak bertanya kepada Umar bin Khattab tentang dua istri Nabi shallallahu 'alaihi wasallam yang bersekongkol menentang kebijaksanaan beliau, tiba-tiba aku merasa segan kepadanya. Suatu hari, ia singgah di suatu tempat, lalu dia masuk ke semak-semak (untuk buang hajat), ketika dia keluar, aku pun langsung menanyakan hal itu kepadanya, dia menjawab; "Mereka adalah Aisyah dan Hafshah." Lalu dia melanjutkan kisahnya; Di masa Jahiliah dulu, kami tidak pernah mengikut sertakan wanita dalam suatu urusan, namun ketika Islam datang, sehingga Allah menyebutkan kebenaran peranan mereka atas kami 


\section{daripada kami tidak mengikut sertakan mereka pada urusan kami... $^{14}$}

Hadis di atas menceritakan tentang kegelisahan Ibn Abbas terhadap kedua istri Nabi yang telah bekerja sama untuk membantah Nabi. Ibn Abbas menanyakan hal tersebut kepada Umar bin Khattab. Kemudian Umar menjelaskan terkait permasalahan yang terjadi bahwa dahulu ketika Zaman Jahiliah wanita tidak pernah dilibatkan dalam urusan apa pun. Hal tersebut dilakukan Umar terhadap istrinya, Pada saat itu, Nabi tidak menemui istrinya dan bahkan tidak tidur bersama istrinya selama 29 hari. Setelah Umar ijin untuk masuk menemui putrinya dan memarahi putrinya, Nabi tersenyum dan kembali untuk menemui istrinya lagi.

Hadis di atas hanya diriwayatkan oleh Bukhari dalam Shahih Bukhari. Penulis tidak menemukan hadis tersebut dalam kitab induk lainnya. Ibn Abbas adalah sahabat rasul yang dekat dengan Nabi, ia sering meriwayatkan hadis Nabi dan tidak berkhianat. ${ }^{15}$ Periwayat kedua adalah 'Ubaid bin Hunain, Nama kunyahnya adalah Abu Abdullah, masyhurnya ia dipanggil at-Tha'i atau al-Madaniy, ia tinggal di Madinah, termasuk dalam thabaqah ketiga, adapun kualitas beliau masuk dalam kategori tsiqqah. ${ }^{16}$ Periwayat selanjutnya adalah Yahya bin Sa'id bin Qais bin 'Amr. Kunyah beliau adalah Abu Sa'id dan masyhurnya adalah Yahya bin Sa'id al-Anshariy. Beliau tinggal

14 Hadis riwayat al-Bukhari nomor 5395 "Carihadis.com," 2019, www.carihadis.com. Diakses pada tanggal 23 September 2019

15 Abu al-Fadl Ahmad bin Ali bin Muhammad al-Kunaniy AlAsqalaniy, Al-Ishabah fi Tamyiz as-Shahabah (Beirut: Daar al-Kutub alIlmiyah, 1995), Juz IV, hlm. 121.

16 Abu al-Fadl Ahmad bin Ali bin Muhammad al-Kunaniy AlAsqalaniy, Taqrib at-Tahdzib (Beirut: Daar al-Kutub al-Ilmiyah, 1995), 283; Ibn Abi Hatim Ar-Razi, Kitab at-Ta'dil wa-Tajrih (Beirut: Daar al-Kutub alIlmiyah, t.t.), 429.

TAHDIS Volume 10 Nomor 2 Tahun 2019 
di Baghdad dan Madinah. Beliau masuk dalam urutan tsiqqah, atsbatunnas. ${ }^{17}$ Terakhir adalah Hammad bin Salamah bin Dinar, kunyah beliau adalah Abu Salamah dan masyhu dipanggil Hammad bin Salamah al-Bashriy, laqob beliau adalah Ibn Abi Shakhrah. Beliau tinggal di Bashrah dan wafat pada tahun 167 $\mathrm{H}$, dan termasuk dalam thabaqah kedelapan. ${ }^{18}$ Melihat paparan di atas, dapat disimpulkan bahwa hadis tersebut termasuk dalam sahihul isnad.

Hadis tersebut hanya diriwayatkan Imam Bukhari. Penjelasan tentang dua wanita yang bertentangan adalah Hafshah dan 'Aisyah. Bahwa Hafshah dikatakan pernah menyakiti perasaan Nabi. Kisah tersebut telah disebutkan dalam tafsir Surat at-Tahrim, bahwa sahabat mendengar isu jika Nabi menceraikan istri-istrinya. ${ }^{19}$ Al-Atsqalany dalam menjelaskan hadis tersebut masih berkutat dalam sinonimitas lafaz-lafaz yang sukar maknanya. Beliau masih berkutat dalam penafsiran Surat at-Tahrim. ${ }^{20}$ Al-Qasthalaniy dalam kitab

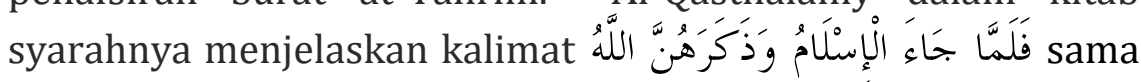
dengan Surat an-Nisa' ayat 19.21

Dalam ranah penafsiran Alquran Ibn 'Asyur menjelaskan di dalam Surat an-Nisa', bahwa hadis di atas adalah sumber

17 Abu al-Fadl Ahmad bin Ali bin Muhammad al-Kunaniy AlAsqalaniy, Tahdzib at-Tahdzib (Beirut: Daar al-Ma'rifah, 1996), 233; AlAsqalaniy, Taqrib at-Tahdzib, 303.

${ }^{18}$ Al-Asqalaniy, Taqrib at-Tahdzib, 238; Abu al-Fadl Ahmad bin Ali bin Muhammad al-Kunaniy Al-Asqalaniy, Lisan al-Mizan (Beirut: Daar Ihya' al-Turats al-Arabiy, 1996), 210.

${ }^{19}$ Badruddin Al-'Aini, Umdat al-Qari (Beirut: Daar Ihya' al-Turats alArabiy, 2003), 484.

20 Abu al-Fadl Ahmad bin Ali bin Muhammad al-Kunaniy AlAsqalaniy, Fath-al-Bari Syarh Shahih al-Bukhariy (Beirut: Daar al-Fikr, 1993), 484.

21 Ahmad bin Muhammad bin Abi Bakr bin Abd al-Malik AlQasthalaniy, Irsyad al-Sariy li Syarh Shahih al-Bukhariy (Mesir: AlMuthaba'ah al-Kubra al-Amiriyah, 1323), Juz VIII, 443.

TAHDIS Volume 10 Nomor 2 Tahun 2019 
dari riwayat lain, bahwa dahulu orang-orang Quraisy dikalahkan oleh perempuan. Hal tersebut menjelaskan bahwa orang-orang Mekkah lebih keras daripada orang Madinah dalam aspek mu'amalah perempuan, karena orang Madinah berasal dari daerah Yaman yang notabenenya masih serumpun dengan Bangsa Arab, dan dari Yaman dahulu budak-budak tersebut berasal. Ibn 'Asyur menambahkan bahwa ketika Zaman Jahiliah, tatkala seorang laki-laki meninggal, maka hak kepemimpinannya diambil alih oleh istrinya. Mereka akan menikahi perempuan, jika mereka menginginkannya dan sebaliknya juga begitu. ${ }^{22}$ Hal ini menunjukkan bahwa, konstruksi sosial masyarakat Jahiliah masih bias gender tanpa memperhatikan perempuan yang juga berhak untuk menikah dengan yang diinginkan.

Az-Zuhaily juga menjelaskan keburukan orang-orang pada zaman Jahiliah. Perempuan pada zaman dahulu adalah sebuah warisan jika suaminya meninggal. Tatkala Abu Qais bin al-Aslat meninggal maka anaknya ingin menikahi istri Abu Qais, maka menikahlah anaknya dengan ibunya sendiri. ${ }^{23}$ Kemudian Allah menurunkan ayat tersebut yang memerintahkan untuk tidak memaksa atau membatasi hak-hak perempuan terkait perkawinan. ${ }^{24}$ Kombinasi antara beberapa penafsiran terebut, dapat disimpulkan bahwa hak-hak perempuan pada zaman Jahiliah masih terbatas dan belum memiliki kebebasan yang sempurna. Pada saat Surat an-Nisa' ayat 19 turun, mulailah belenggu tersebut dapat dilepaskan. Pada dasarnya, hak

22 Muhammad Thahir Ibn Asyur, Tafsir At-Tahrir wa At-Tanwir (Tunisia: Daar Sahnun, 1997), Juz II, 388.

${ }^{23}$ Wahban bin Musthofa Az-Zuhailiy, At-Tafsir al-Munir fi al-Aqidah wa al-Syari'ah wa al-Manhaj (Dimsyiq: Daar al-Fikr al-Ma'ashir, 1418), Juz 4, 80.

${ }^{24}$ Mujiruddin bin Muhammad Al-Alimiy, Fath ar-Rahman fi Tafsir al-Qur'an (Daar an-Nawadir, 2009), Juz II, 102.

TAHDIS Volume 10 Nomor 2 Tahun 2019 
tersebut sudah diakui oleh Tuhan dan Nabi, tetapi penulis beranggapan bahwa untuk keadaan yang modern ini masih perlu adanya reinterpretasi terhadap hadis di atas untuk melegitimasi adanya hak-hak perempuan yang perlu diakui.

\section{Reinterpretasi Hadis Pengakuan atas Hak-hak Perempuan}

Pemahaman kontekstual dalam memahami hadis telah menjadi sebuah diskursus tersendiri. Pemahaman ini mengombinasikan keilmuan agama (Alquran, tafsir, hadis, fiqh, tasawuf) dan faktor eksternal yang dalam hal ini penulis fokus kepada analisis kebahasaan dan gender. Pendekatan analisis gender dalam kajian teks keagamaan (Alquran dan hadis) penting dilakukan untuk mengetahui aspek teologis-dogmatis atau aspek sosiologis-historis. Melibatkan analisis gender berarti menghindari memahami teks keagamaan secara tekstual-harfiah. Langkah tersebut merupakan salah satu perkembangan dalam menjawab problematik sosial, ketika masih berkembangnya pemahaman bias gender yang berimplikasi terhadap ketidakadilan dan kekerasan terhadap perempuan. Padahal, prinsip ajaran Islam adalah al-musawah, al-'adalah, al-syura, al-ma'ruf, dan al-ihsan. ${ }^{25}$

Pemuliaan perempuan di dalam hadis telah menjadi fakta realistis, meskipun terdapat beberapa tema dalam kutub al-tis'ah yang dijustifikasi sebagai hadis misoginis. ${ }^{26}$ Akan tetapi, masih perlu adanya reinterpretasi terhadap hadis-hadis yang sensitif terhadap perempuan, sebagai perlawanan atas pemahaman yang mendiskreditkan perempuan dengan nama agama. Salah satu pemikir muslim yang memperhatikan entitas

25 Mustaqim, 100.

${ }^{26}$ Agung Danarta, Perempuan Periwayat Hadis (Yogyakarta: Pustaka Pelajar, 2013), 297-304. 
seorang perempuan adalah Muhammad al-Ghazali. Dalam karyanya, al-Ghazali menyebutkan beberapa sub bab tentang perempuan. Beliau mengomentari hadis-hadis yang sensitif terhadap perempuan, misalnya tentang larangan untuk melihat wajah perempuan yang akan menimbulkan syahwat bagi lakilaki. Menurutnya, kebebasan perempuan dalam menunjukkan eksistensinya lebih diutamakan daripada harus membebaskan syahwat seorang diri. Melampiaskan syahwat karena terpengaruh wajah perempuan adalah penyakit psikologis yang dipengaruhi oleh kultur daerah. Ketika kultur daerah berubah maka penyakit tersebut akan hilang perlahan. ${ }^{27}$ Maka sudah semestinya pemahaman tersebut dalam konteks sekarang perlu direduksi, supaya kaum perempuan tidak merasa didiskreditkan hanya karena wajah mereka yang tidak tertutup.

\section{Pengujian dengan Ayat-ayat Alquran}

Dalam memahami hadis, al-Ghazali menawarkan bahwa hadis harus diuji terlebih dahulu dengan Alquran. Hal tersebut didasarkan bahwa tidak mungkin hadis yang sahih bertentangan dengan ayat Alquran, karena Alquran sebagai sumber otoritas pertama, sedangkan hadis menjadi penjelas Alquran. ${ }^{28}$ Ayat tentang pengakuan Allah terhadap perempuan disebutkan dalam beberapa Surah. Pertama di dalam Surah alMu'min: 40

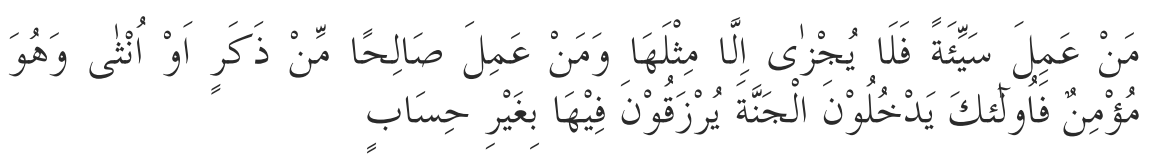

${ }^{27}$ Rabi' bin Hadi Al-Madkhaliy, Membela Sunnah Nabawy: Jawaban Terhadap Buku Studi Kritis atas Hadis Nabi (Jakarta Timur: Pustaka AlKautsar, 1995), 68-70.

${ }^{28}$ Suryadi, Metode Kontemporer Pemahaman Hadis Nabi: Perspektif Muhammad al-Ghazali dan Yusuf al-Qardhawiy, 82.

TAHDIS Volume 10 Nomor 2 Tahun 2019 
Artinya:

Barang siapa mengerjakan perbuatan jahat, maka dia akan dibalas sebanding dengan kejahatan itu. Dan barang siapa mengerjakan kebajikan, baik laki-laki maupun perempuan sedangkan dia dalam keadaan beriman, maka mereka akan masuk surga, mereka diberi rezeki di dalamnya tidak terhingga. ${ }^{29}$

Al-Maturidy menafsirkan ayat di atas bahwa tidak ada pengecualian bagi seseorang yang ingin beramal baik, maka orang tersebut berhak untuk masuk ke dalam surga dan mendapat rezeki yang tidak terbatas. ${ }^{30}$ Hal tersebut juga ditambah dengan at-Thabariy, bahwa lafaz صَالِحًَا sama artinya dengan إخير 31 Mafhum mukhalafah dari ayat tersebut adalah Allah tidak membeda-bedakan orang yang akan masuk surga melalui amalnya, baik laki-laki atau perempuan memiliki hak yang sama dalam memperjuangkan surga-Nya. Maka di sini Allah telah mengakui eksistensi keberadaan perempuan sama dengan makhluk lainnya. Perempuan dapat melakukan apa pun yang ia bisa lakukan tanpa mendiskreditkan laki-laki. Dalam Qs. Al Imran: 195, Allah Swt. berfirman:

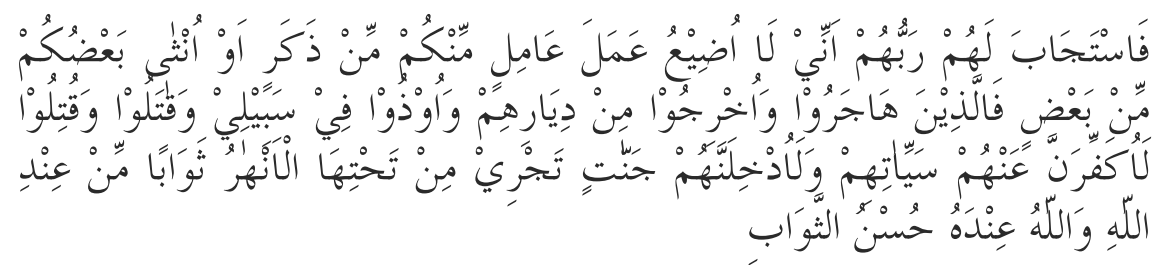

${ }^{29}$ Lajnah Pentashihan Mushaf al-Qur'an, Qur'an Kemenag (Jakarta: Kementrian Agama Indonesia, 2005).

30 Muhammad bin Muhammad bin Mahmud Al-Maturidiy, Tafsir alMaturidiy (Beirut: Daar al-Kutub al-Ilmiyah, 2005), Juz IX, hlm. 31.

31 Muhammad bin Jarir bin Yazid bin Katsir bin Ghalib AthThabariy, Jami'u al-Bayan fi Ta'wil al-Qur'an (Muassasah Ar-Risalah, 2000), Juz XXI, hlm. 390. 
Artinya:

Maka Tuhan mereka memperkenankan permohonannya (dengan berfirman), "Sesungguhnya Aku tidak menyianyiakan amal orang yang beramal di antara kamu, baik laki-laki maupun perempuan, (karena) sebagian kamu adalah (keturunan) dari sebagian yang lain. Maka orang yang berhijrah, yang diusir dari kampung halamannya, yang disakiti pada jalan-Ku, yang berperang dan yang terbunuh, pasti akan Aku hapus kesalahan mereka dan pasti Aku masukkan mereka ke dalam surga-surga yang mengalir di bawahnya sungai-sungai, sebagai pahala dari Allah. Dan di sisi Allah ada pahala yang baik." (Ali 'Imran:195)

Hadis tersebut turun tatkala Ummu Salamah bertanya kepada Nabi, bagaimana keadaan laki-laki yang hijrah denganmu tapi tanpa membawa istrinya? Kemudian Nabi

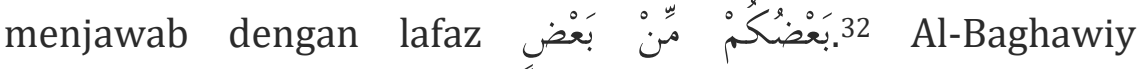
menambahkan, kejadian tersebut terjadi ketika Ummu Salamah menanyakan keberadaan perempuan, mengapa hanya laki-laki yang disebutkan ketika membahas masalah hijrah? Maka kemudian Allah menurunkan ayat tersebut. ${ }^{33}$ Ayat tersebut menceritakan bahwa keberadaan perempuan tidak dapat ditiadakan dalam hal apa pun. Dalam ranah publik laki-laki tidak dapat melepaskan peran perempuan begitu saja. Dalam hal sekecil apa pun, perempuan pasti memiliki peran untuk menyelesaikan tugas di dunia.

32 Abu al-Hasan Ali bin Muhammad bin Muhammad bin Habib alBashriy al-Baghdadiy Al-Mawardiy, Tafsir al-Mawardiy (Beirut: Daar alKutub al-Ilmiyah, 1998), Juz I, hlm: 443.

33 Abu Muhammad al-Husain bi Mas'ud bin Muhammad bin alFara'Al-Baghawiy, Ma'alimu at-Tanzil fi Tafsir al-Qur'an (Beirut: Daar Ihya' al-Turats al-Arabiy, 1420), Juz I, hlm: 512.

TAHDIS Volume 10 Nomor 2 Tahun 2019 
Dari paparan beberapa penafsir di atas, penulis berasumsi bahwa hadis tentang pengakuan hak-hak perempuan tidak bertentangan dengan ayat Alquran. Perempuan memiliki peran yang sama dengan laki-laki. Kebahagiaan seorang laki-laki tidak dapat diukur dengan hanya apa yang dilakukannya, tetapi peran perempuan juga menjadi faktor untuk terwujudnya sebuah kebahagiaan. Selain itu, keberadaan perempuan juga diakui oleh Allah dengan penggunaannya lafaz أو, artinya bahwa perempuan juga memiliki kebebasan individu dalam melakukan apa pun untuk berkiprah di ranah publik, dan mendapatkan kebahagiaan di dunia dan akhirat.

\section{Mengkonfirmasi dengan Hadis lain ${ }^{34}$}

Maksud dari langkah ini adalah hadis yang dijadikan obyek tidak bertentangan dengan hadis lain yang lebih sahih. Menurut al-Ghazali, pengujian hadis dengan hadis mengisyaratkan bahwa untuk memutuskan suatu hukum dari hadis tidak dapat cukup hanya satu hadis. Pembandingan dengan hadis yang berkaitan menjadikan sebuah validitas hadis lebih mudah untuk dipahami. ${ }^{35}$

Adapun hadis yang berkaitan dengan pengakuan hakhak perempuan sebagai berikut:

- Hak Memperlakukan Perempuan dengan Baik

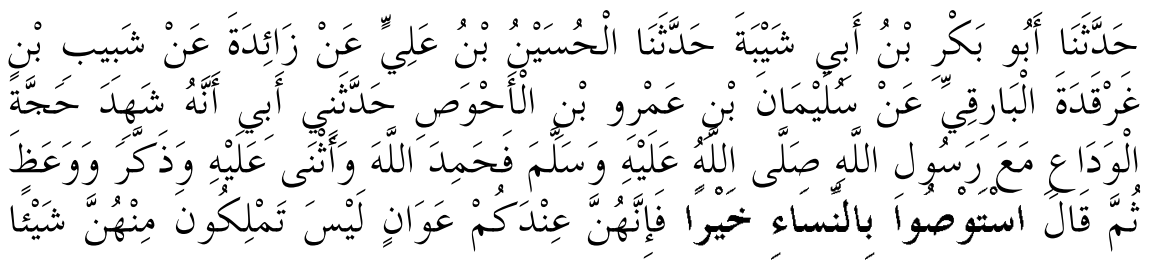

${ }^{34}$ Suryadi, Metode Kontemporer Pemahaman Hadis Nabi: Perspektif Muhammad al-Ghazali dan Yusuf al-Qardhawiy, 83.

35 Al-Ghazali, As-Sunnah An-Nabawiyyah baina Ahli al-Fiqh wa Ahli al-Hadis, 142. 
144 | Hadis Pengakuan Atas Hak-Hak Perempuan

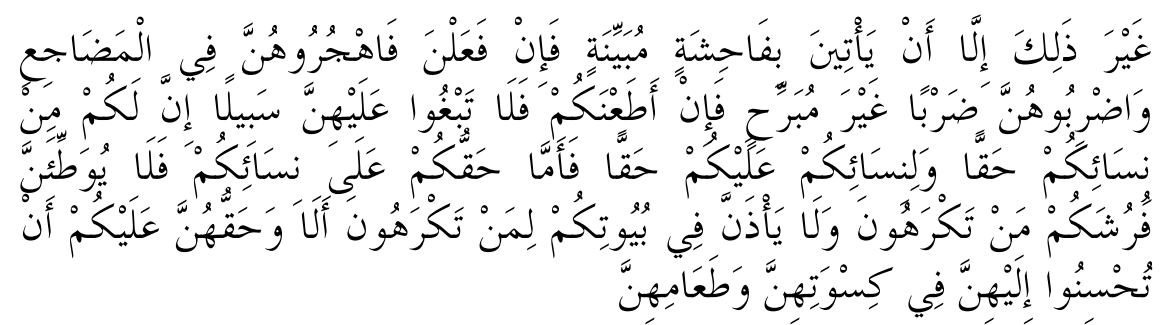

Artinya:

Telah menceritakan kepada kami Abu Bakr bin Abu Syaibah berkata, telah menceritakan kepada kami Al Husain bin Ali dari Za idah dari Syabib bin Gharqadah Al Bariq dari Sulaiman bin Amru bin Al Ahwash berkata, telah menceritakan kepadaku Bapakku bahwasanya ia pernah menghadiri haji wada' bersama Rasulullah shallallahu 'alaihi wasallam. Beliau memuji Allah dan mengagungkan-Nya, mengingatkan dan memberi wejangan. Setelah itu beliau bersabda: "Perlakukanlah istri-istri kalian dengan baik, karena mereka adalah teman di sisi kalian. Kalian tidak memiliki suatu apa pun dari mereka selain itu. Kecuali jika mereka berbuat zina dengan terang-terangan. Jika mereka melakukannya maka tinggalkan mereka di tempat tidur dan pukullah dengan pukulan yang tidak melukai. Apabila mereka menaati kalian maka janganlah berbuat sewenangwenang terhadap mereka. Sungguh, kalian mempunyai hak dari istri-istri kalian dan istri-istri kalian mempunyai dari kalian. Adapun hak kalian terhadap istri kalian; jangan menginjakkan di tempat tidur kalian orang yang kalian benci dan jangan diizinkan masuk rumah-rumah kalian terhadap orang yang kalian benci. Dan sungguh hak mereka atas kalian; hendaknya memperlakukan 
mereka dengan baik dalam masalah pakaian dan makanan."36

Hadis di atas merupakan salah satu perintah Nabi untuk memperlakukan perempuan dengan baik. Lafaz النّّسَاء dalam hadis tersebut memiliki makna umum. Artinya, tidak terpacu kepada seseorang yag memiliki suami. Maka wajib bagi seseorang untuk mu'amalah bil ma'ruf (berkomunikasi dengan baik) kepada perempuan. Salah satu cara berkomunikasi dengan baik yakni dengan mengakui keberadaan perempuan seutuhnya. Mendukung haknya sebagai perempuan, menunjang semua apa yang dibutuhkan.

- Prinsip Meritrokasi ${ }^{37}$

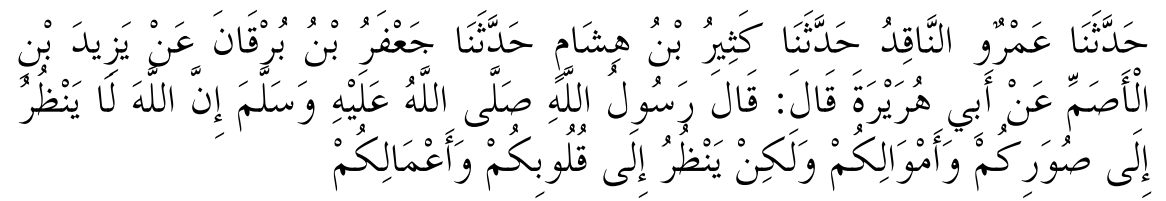

Artinya:

Telah menceritakan kepada kami 'Amru An Naqid; Telah menceritakan kepada kami Katsir bin Hisyam; Telah menceritakan kepada kami Ja'far bin Burqan dari Yazid bin Al Asham dari Abu Hurairah dia berkata; Rasulullah shallallahu 'alaihi wasallam bersabda: "Sesungguhnya Allah tidak melihat kepada rupa dan harta kalian, tetapi Allah melihat kepada hati dan amal kalian." 38

${ }^{36}$ Al-Quzwainiy, Sunan Ibn Majah, No: 1841; "Carihadis.com."

37 Meritrokrasi adalah sistem yang memberikan kesempatan kepada seseorang untuk memimpin berdasarkan kemampuan atau prestasi, bukan kekayaan, senioritas, dan sebagainya. Kementerian Pendidikan dan Kebudayaan, “KBBI Offline” (Jakarta: Badan Pengembangan Bahasa, 2016).

38 An-Nisabury, Shahih Muslim, No: 3890; "Carihadis.com." 
Hadis di atas berbicara tentang seseorang yang akan diangkat menjadi pemimpin. Allah dalam memilih sosok pemimpin tidak melihat rupa dan harta seseorang, tetapi melihat visi, misi, dan track record seseorang sebagai sarana untuk melihat kredibilitas orang tersebut. Dalam prinsip Qira'ah Mubadalah, ${ }^{39}$ hadis di atas tidak hanya ditujukan kepada kaum laki-laki, tapi perempuan juga berhak untuk mendapatkan hak memimpin sebuah sistem. Maka penerapan dari hadis di atas adalah Allah tidak melihat laki-laki atau perempuan, tetapi Allah melihat hati dari seseorang perempuan yang siap untuk berjuang dan memperjuangkan sistem yang akan dipimpinnya.

\section{Pengujian dengan Fakta Historis}

Perempuan di masa Nabi memiliki eksistensi yang telah diakui oleh lapisan masyarakat umumnya. Nabi mempersilakan perempuan untuk melakukan sesuatu untuk bertahan hidup, selama masih dalam koridor syari'at. Peran perempuan juga memiliki varian yang berbeda, seperti peran Khadijah sebagai istri Nabi untuk membantu menenangkan Nabi ketika menerima wahyu. Khadijah juga memberikan seluruh hartanya untuk membantu dakwah Nabi, sedangkan dakwah Nabi adalah urusan publik yang membahayakan nyawa dan harta. ${ }^{40}$ Meskipun demikian, Nabi tidak melarang perempuan untuk ikut campur dalam urusan laki-laki, juga urusan publik. Hal tersebut mencerminkan bahwa, perempuan memiliki hak untuk menunjukkan perannya dalam bersosial di masyarakat.

Keberadaan perempuan semata-mata bukan sebagai penghambat untuk menyejahterakan perkembangan masyarakat. Hal tersebut dicerminkan dalam larangan Nabi

${ }^{39}$ Abdul Kodir, Qira'ah Mubadalah, 60.

40 Phillip K Hitti, Histoy of The Arabs, I ( Jakarta Selatan: Zaman, 2018), 140-41.

TAHDIS Volume 10 Nomor 2 Tahun 2019 
kepada seseorang yang menghambat hak-hak perempuan untuk pergi ke masjid. Perempuan memiliki hak untuk bepergian ke masjid sebagai sarana untuk mengambil manfaat. ${ }^{41}$ Pelarangan yang pernah terjadi karena kondisi sosial pada zaman dahulu yang masih berbahaya untuk perempuan. Selain itu, kejahatan dan syahwat dari orang yang masih di luar koridor Islam belum dapat dibendung. Maka dari itu, perlu adanya kacamata modern dalam memahami hadis pelarangan perempuan ke masjid.

Profesi Nabi sebagai sosok pemimpin umat sekaligus pemimpin keluarga menjadi tendensi dasar untuk berbuat baik kepada perempuan. Keluarga yang di dalamnya meliputi suami, istri, dan anak menjadi medan untuk menumbuhkan nilai-nilai kemanusiaan. Relasi Nabi dengan istrinya Aisyah menjadi tolok ukur idealis sebagai contoh untuk mendukung adanya keberadaan perempuan di ranah keluarga. ${ }^{42}$ Keberadaan perempuan di dalam ranah keluarga memiliki peran yang berbeda, perempuan memiliki hak-hak untuk mendapat kasih sayang, mendapat nafkah. Hal yang demikian adalah penjelmaan nilai-nilai kemanusiaan dalam mengakui keberadaan perempuan.

\section{Pengujian dengan Kebenaran Ilmiah}

Hadis dapat diaplikasikan jika tidak bertentangan dengan kebenaran ilmiah. ${ }^{43}$ Artinya hadis tersebut memiliki pendukung berupa ilmu pengetahuan sebagai legitimasi supaya hadis tersebut dapat diamalkan. Ilmu pengetahuan sebagai produk baru memiliki peran penting sebagai upaya untuk

${ }^{41}$ Abdul Kodir, Qira'ah Mubadalah, 451-52.

$42 \mathrm{Abu}$ Isa Muhammad bin Saurah At-Turmudziy, Sunan AtTurmudziy (Beirut: Daar al-Fikr, 1994), No. 4269; dalam Abdul Kodir, Qira'ah Mubadalah, 325.

43 Suryadi, Metode Kontemporer Pemahaman Hadis Nabi: Perspektif Muhammad al-Ghazali dan Yusuf al-Qardhawiy, 85. 
memahami hadis dengan pemahaman kontemporer. Dalam menguji hadis tentang pengakuan hak-hak perempuan, penulis menggunakan analisis kebahasaan. Bahwa di dalam hadis

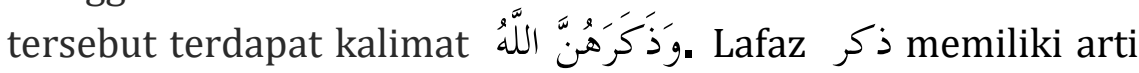
menyebutkan dan mengucapkan. ${ }^{44}$ Artinya Allah menyebutkan hak-hak yang memang dimiliki oleh perempuan, mafhum mukhalafahnya adalah Allah "mengakui" keberadaan perempuan dan juga mengakui hak-hak mereka. Hal tersebut ditambah dalam redaksi selanjutnya bahwa Ummu Salamah membela diri tatkala Umar ingin memutuskan sesuatu tanpa berdiskusi dengan istrinya. Ummu Salamah juga menganalogikan dengan rumah tangga Nabi yang selalu mendiskusikan sesuatu dengan istrinya. Maka Allah dan Nabi, dalam hal ini memiliki peran yang signifikan dalam pengakuan hak-hak perempuan. Secara tidak langsung, keliru jika terdapat argumen yang menyatakan bahwa Nabi dan Allah mendiskreditkan perempuan.

Peran perempuan di zaman sekarang telah dilegitimasi oleh beberapa penelitian. Hal tersebut karena pihak pemerintah yang bekerja sama dengan para ulama di Indonesia memiliki peran penting untuk mengangkat eksistensi peran dan hak-hak perempuan. Indonesia sebagai negara yang menjunjung hak asasi manusia telah menetapkan beberapa peraturan untuk menghindari adanya diskriminasi terhadap perempuan. Ketetapan yang telah dibuat tidak lain menggunakan teori gender, yang mana teori ini menjunjung tinggi nilai-nilai keadilan dalam konstruksi sosial. Gender memiliki fokus terhadap kebudayaan yang lahir di Indonesia, yang mana kebudayaan tersebut tidak masuk dalam ranah

${ }^{44}$ Ahmad Warson Munawwir, Kamus Arab-Indonesia Al-Munawwir, II (Surabaya: Pustaka Progresif, 2007), 448.

TAHDIS Volume 10 Nomor 2 Tahun 2019 
teologis, tetapi masih dalam ranah konstruksi sosialis. ${ }^{45}$ Maka dari itu, perspektif gender memiliki peran penting dalam pengangkatan hak-hak perempuan dalam mengkaji teks-teks keagamaan.

Hadis yang dijadikan penulis sebagai objek kajian, harus dipahami dengan perspektif gender, keadilan, dan kemaslahatan. Laki-laki zaman dahulu memiliki prioritas dan otoritas tinggi ketika tampil di publik, hal tersebut tercermin di dalam perkataan Umar bin Khattab yang memutuskan perkara tanpa sepengetahuan istrinya. Maka di zaman kontemporer ini, perempuan berhak untuk turut andil dalam memutuskan perkara yang masih dalam jangkauannya. Perempuan juga berhak untuk menjadi pemimpin dalam suatu organisasi, pemerintahan, dan sistem. Selama kredibilitas dan kemampuan perempuan mampu untuk menjangkaunya, maka perempuan berhak untuk menunjukkan eksistensinya. Eksistensi seorang perempuan ketika turut andil dalam mengurus suatu sistem, bukan lagi dipahami sebagai pembawa sial atau ciri-ciri kemunduran Islam, tetapi harus dipahami sebagai penunjang kemaslahatan masyarakat. Maka dengan paradigma tersebut, hak-hak perempuan bukan lagi sekedar opsi sekunder dalam ranah publik, tetapi menjadi prioritas yang perlu diperjuangkan.

\section{Kesimpulan}

Diskriminasi terhadap perempuan masih menjadi momok bagi kaum perempuan di Indonesia. Pemaknaan terhadap teks-teks keagamaan menjadi senjata utama untuk melegitimasi bahwa perempuan tidak memiliki peran penuh dibanding dengan laki-laki. Hal tersebut ditambah masih

45 Riant Nugroho, Gender dan Strategi Pengarustamaannya di Indonesia (Yogyakarta: Pustaka Pelajar, 2011), 7.

TAHDIS Volume 10 Nomor 2 Tahun 2019 
terdapat beberapa dai di Indonesia yang masih memahami hadis tanpa mengombinasikan dengan ilmu-ilmu kontemporer. Untuk menyelesaikan problematik yang kontemporer, maka diperlukan juga metode kontemporer untuk memahaminya. Hadis tentang permasalahan Ummu Salamah yang diberlakukan tidak adil perlu dipandang dengan kacamata modern, bahwa termasuk dalam diskriminasi hak-hak perempuan. Maka dari itu, Al-Ghazali dalam hal ini menawarkan empat metode untuk memahami hadis; pengujian dengan Alquran, menguji dengan hadis yang lain, melihat fakta historis dari hadis, dan pengujian dengan kebenaran ilmiah. Dengan bantuan metode tersebut dan ditambah dengan analisis kebahasaan, maka penulis berpendapat bahwa sudah semestinya perempuan diakui keberadaannya dan didukung hak-hak yang perlu diperjuangkan. Salah satu dukungan yang dapat ditempuh adalah dengan mempersilakan perempuan untuk menjadi pemimpin, memberikan hak perempuan untuk tampil di publik, dan mengikutsertakan peran perempuan di setiap permasalahan. 


\section{DAFTAR PUSTAKA}

Abbas, Hasyim. Kritik Matan Hadis. Yogyakarta: Teras, 2004.

Abdul Kodir, Faqihuddin. Qira'ah Mubadalah. Yogyakarta: IRCiSoD, 2019.

Al-'Aini, Badruddin. Umdat al-Qari. Beirut: Daar Ihya' al-Turats al-Arabiy, 2003.

Al-Alimiy, Mujiruddin bin Muhammad. Fath ar-Rahman fi Tafsir Alquran. Daar an-Nawadir, 2009.

Al-Asqalaniy, Abu al-Fadl Ahmad bin Ali bin Muhammad alKunaniy. Al-Ishabah fi Tamyiz as-Shahabah. Beirut: Daar al-Kutub al-Ilmiyah, 1995.

_-_ Fath-al-Bari Syarh Shahih al-Bukhariy. Beirut: Daar alFikr, 1993.

- — L Lisan al-Mizan. Beirut: Daar Ihya' al-Turats al-Arabiy, 1996.

_-_. Tahdzib at-Tahdzib. Beirut: Daar al-Ma'rifah, 1996.

- — Taqrib at-Tahdzib. Beirut: Daar al-Kutub al-Ilmiyah, 1995.

Al-'Audah, Salman bin Fadh. Hiwar Hadi Ma'a Muhammad alGhazali. Haran Burairah, 1409.

Al-Baghawiy, Abu Muhammad al-Husain bi Mas'ud bin Muhammad bin al-Fara'. Ma'alimu at-Tanzil fi Tafsir Alquran. Beirut: Daar Ihya' al-Turats al-Arabiy, 1420.

Al-Bukhari, Abu Abdullah Muhammad bin Ismail bin Ibrahim bin Al-Mughiroh. Shahih Bukhari. Daar Ibn Katsir, 1993.

Al-Ghazali, Muhammad. Al-Sunnah Al-Nabawiyyah baina Ahli al-

Fiqh wa Ahli al-Hadis. Mesir: Daar al-Kitab al-Mishriy, 2012.

-_- Al-Sunnah Nabawiyyah Bayna Ahl Al-Fiqh wa Ahl AlHadis. Kairo: Dar al-Syuruq, 2001.

-_- As-Sunnah An-Nabawiyyah baina Ahli al-Fiqh wa Ahli alHadis. Mesir: Daar al-Kutub al-Mishriy, 2012. 
-——. At-Thariq min Huna. Mesir: Daar Syuruq, 1992.

- - Fiqhu al-Sirah. Kairo: Dar ar-Rayyan Li at-Turats, 1987.

-_- Laisa min al-Islam. Kairo: Maktabah Wahbah, 1991.

- - - Studi Kritis atas Hadis Nabi. Bandung: Mizan, 1996.

Al-Madkhaliy, Rabi' bin Hadi. Membela Sunnah Nabawy: Jawaban Terhadap Buku Studi Kritis atas Hadis Nabi. Jakarta Timur: Pustaka Al-Kautsar, 1995.

Al-Maturidiy, Muhammad bin Muhammad bin Mahmud. Tafsir al-Maturidiy. Beirut: Daar al-Kutub al-Ilmiyah, 2005.

Al-Mawardiy, Abu al-Hasan Ali bin Muhammad bin Muhammad bin Habib al-Bashriy al-Baghdadiy. Tafsir al-Mawardiy. Beirut: Daar al-Kutub al-Ilmiyah, 1998.

Al-Qardhawy, Yusuf. Asy-Syekh Al-Ghazali Kama 'Araftuhu. Kairo: Dar al-Syuruq, 1999.

Al-Qasthalaniy, Ahmad bin Muhammad bin Abi Bakr bin Abd alMalik. Irsyad al-Sariy li Syarh Shahih al-Bukhariy. Mesir:

Al-Muthaba'ah al-Kubra al-Amiriyah, 1323.

Al-Quzwainiy, Ibn Majah Abu Abdullah Muhammad bin Yazid.

Sunan Ibn Majah. Daar Ihya' al-Turats al-Arabiy, t.t.

An-Nisabury, Abu Al-Husain Muslim bin Al-Hajjaj bin Muslim

Al-Qusyairi. Shahih Muslim. Beirut: Daar al-Kutub alIlmiyah, 1992.

Ar-Razi, Ibn Abi Hatim. Kitab at-Ta'dil wa-Tajrih. Beirut: Daar al-Kutub al-Ilmiyah, t.t.

Ath-Thabariy, Muhammad bin Jarir bin Yazid bin Katsir bin

Ghalib. Jami'u al-Bayan fi Ta'wil Alquran. Muassasah ArRisalah, 2000.

At-Turmudziy, Abu Isa Muhammad bin Saurah. Sunan AtTurmudziy. Beirut: Daar al-Fikr, 1994.

Az-Zuhailiy, Wahban bin Musthofa. At-Tafsir al-Munir fi alAqidah wa al-Syari'ah wa al-Manhaj. Dimsyiq: Daar alFikr al-Ma'ashir, 1418. 
“Carihadis.com,” 2019. www.carihadis.com.

Danarta, Agung. Perempuan Periwayat Hadis. Yogyakarta: Pustaka Pelajar, 2013.

Hitti, Phillip K. Histoy of The Arabs. I. Jakarta Selatan: Zaman, 2018.

Ibn Asyur, Muhammad Thahir. Tafsir At-Tahrir wa At-Tanwir.

Tunisia: Daar Sahnun, 1997.

Imarah, Muhammad. Gejolak Pemikiran Syekh Muhammad AlGhazali, 2008. www.kaunee.com.

Ismail, Syuhudi. Kaidah Kesahihan Sanad Hadis. IV. Jakarta: PT. Bulan Bintang, 2014.

Jangan Ajari Umat Islam tentang Kesetaraan Gender - Ustadz Adi Hidayat. Diakses $16 \quad$ September 2019. https://www.youtube.com/watch?v=5bjcY6qIun4.

Kementrian Pendidikan dan Kebudayaan. "KBBI Offline." Jakarta: Badan Pengembangan Bahasa, 2016.

Lajnah Pentashihan Mushaf Alquran. Qur'an Kemenag. Jakarta:

Kementrian Agama Indonesia, 2005.

Munawwir, Ahmad Warson. Kamus Arab-Indonesia Al-

Munawwir. II. Surabaya: Pustaka Progresif, 2007.

Mustaqim, Abdul. Ilmu Ma'anil Hadis. Yogyakarta: Idea Press, 2016.

Nugroho, Riant. Gender dan Strategi Pengarustamaannya di Indonesia. Yogyakarta: Pustaka Pelajar, 2011.

"Perempuan Indonesia Masih dalam Belenggu Diskriminasi Halaman all - Kompas.com." Diakses 16 September 2019.

https://nasional.kompas.com/read/2016/08/21/1619

2911/perempuan.indonesia.masih.dalam.belenggu.diskr iminasi?page $=$ all.

Purwaningsih, Sri. "Kritik Terhadap Rekonstruksi Metode

Pemahaman Hadis Muhammad Al-Ghazali." Jurnal 
Theologia 28, no. 1 (14 September 2017): 75-102. https://doi.org/10.21580/teo.2017.28.1.1189.

Qardhawi, Yusuf. Syaikh Muhammad al-Ghazali yang Saya Kenal. Jakarta: Rabbani Press, 1999.

Suryadi. Metode Kontemporer Memahami Hadis Nabi. Yogyakarta: Teras, 2008.

-C- Metode Kontemporer Pemahaman Hadis Nabi: Perspektif Muhammad al-Ghazali dan Yusuf alQardhawiy. Yogyakarta: Teras, 2008.

Suryadi, Muhammad Alfatih Suryadilaga. Metodologi Penelitian Hadis. Yogyakarta: TH-Press, 2009.

Suryadilaga, Muhammad Alfatih. Ilmu Sanad Hadis. Yogyakarta: Idea Press, 2017.

Uwais, Abdul al-Halim. Al-Syaikh Muhammad Al-Ghazali: Marahil Azhimah fi Hayah Mujahid Azhim. Kairo: Dar alSyahwah, 1993. 